\title{
Works by Jacques Derrida Cited
}

The following list gives full publication information for all works by Jacques Derrida quoted or cited in these chapters. Works are in alphabetical order of their title in the published English translation when one is available, followed by the citation of the original French edition. Untranslated works are listed only by their French titles. Short titles used to refer to the works throughout are given in parentheses. Unless otherwise indicated, all quotations are from the published English translations, which have occasionally been modified.

(Acts) Acts of Literature. Edited by Derek Attridge. New York and London: Routledge, 1992.

("Afterword") "Afterword: Toward an Ethic of Discussion." Translated by Samuel Weber. In Limited; "Postface: Vers une éthique de la discussion." See Limited.

(Alibi) Without Alibi. Edited and translated by Peggy Kamuf. Stanford: Stanford University Press, 2002.

(Animal) The Animal that Therefore I Am. Edited by Marie-Louise Mallet. Translated by David Wills. New York: Fordham University Press, 2008; L'Animal que donc je suis. Edited by Marie-Louise Mallet. Paris: Galilée, 2006.

(“Ants”) “Ants.” Translated by Eric Prenowitz. In Oxford Literary Review 24 (2002); "Fourmis." In Lectures de la différence sexuelle. Edited by Mara Negrón. Paris: Éditions des femmes, 1994.

(“Aphorism”) “Aphorism Countertime.” Translated by Nicholas Royle. In Psyche II; “L’Aphorisme à contretemps.” In Psyché II. 
(Archive) Archive Fever: A Freudian Impression. Translated by Eric Prenowitz. Chicago: University of Chicago Press, 1996; Mal d'archive, une impression freudienne. Paris: Galilée, 1995.

(“As If”) “As If It Were Possible, 'Within Such Limits' ...” In Paper. "Comme si c'était possible, 'within such limits' ..." In Papier machine (see Paper).

("Autoimmunity") "Autoimmunity: Real and Symbolic Suicides." Translated by Pascale-Anne Brault and Michael Naas. In Philosophy in a Time of Terror: Dialogues with Jürgen Habermas and Jacques Derrida. Edited by Giovanna Borradori. Chicago: University of Chicago Press, 2003; Derrida and Jürgen Habermas, Le "Concept" du 11 septembre: Dialogues à New York (octobre-décembre 2001), avec Giovanna Borradori. Paris: Galilée, 2003.

(“Avances”) “Avances.” Preface to Serge Margel, Le Tombeau du dieu artisan. Paris: Minuit, 1995.

("Barthes") “The Deaths of Roland Barthes." In Work; "Les Morts de Roland Barthes." In Chaque fois.

(Beast) The Beast and the Sovereign, Volume I. Edited by Michel Lisse, Marie-Louise Mallet, and Ginette Michaud. Translated by Geoffrey Bennington. Chicago: University of Chicago Press, 2009; La Bête et le souverain I, 2000-2001. Edited by Michel Lisse, MarieLouise Mallet, and Ginette Michaud. Paris: Galilée, 2008.

("Before") "Before the Law." Translated by Avital Ronell and Christine Roulston. In Acts; "Préjugés: Devant la loi." In Derrida et al., La Faculté de juger. Paris: Minuit, 1985.

("Book") “The Book to Come.” In Paper; "Le Livre à venir." In Papier machine (see Paper).

(Chaque fois) Chaque fois unique, la fin du monde. Paris: Galilée, 2003 (see Work).

(Cinders) Cinders. Edited and translated by Ned Lukacher. Lincoln: University of Nebraska Press, 1991 [bilingual edition]; Feu la cendre. Paris: Éditions des femmes, 1987. 
(Circumfession) Circumfession. Translated by Geoffrey Bennington. In Geoffrey Bennington and Jacques Derrida. Jacques Derrida. Chicago: University of Chicago Press, 1993; Circumfession. In Geoffrey Bennington and Jacques Derrida, Jacques Derrida. Paris: Seuil, 1991.

(Counterpath) Catherine Malabou and Derrida, Counterpath: Traveling with Jacques Derrida. Translated by David Wills. Stanford: Stanford University Press, 2004; Catherine Malabou and Derrida, La Contre-allée. Paris: La Quinzaine Littéraire and Louis Vuitton, 1999.

(Demeure) Demeure: Fiction and Testimony. Translated by Elizabeth Rottenberg. Stanford: Stanford University Press, 1998; Demeure, Maurice Blanchot. Paris: Galilée, 1998.

(Derrida) Derrida. Edited by Marie-Louis Mallet and Ginette Michaud. Paris: Cahiers de l'Herne, 2004.

(Dissemination) Dissemination. Translated by Barbara Johnson. Chicago: University of Chicago Press, 1981; La Dissemination. Paris: Éditions du Seuil, 1972.

(Ear) The Ear of the Other: Otobiography, Transference, Translation. Edited by Christie V. McDonald. Translated by Avital Ronell and Peggy Kamuf. New York: Schocken Books, 1985; Otobiographies: L'enseignement de Nietzsche et la politique du nom propre. Paris: Galilée, 1984.

(Eyes) Eyes of the University: Right to Philosophy 2. Translated by Jan Plug and others. Stanford: Stanford University Press, 2004; Du droit à la philosophie. Paris: Galilée, 1990 (see also Philosophy).

("Faith") "Faith and Knowledge: The Two Sources of 'Religion' at the Limits of Reason Alone." Translated by Samuel Weber, in Derrida, Acts of Religion. Edited by Gil Anidjar. New York: Routledge, 2002; "Foi et savoir: Les deux sources de la 'religion' aux limites de la simple raison." In Derrida and Gianni Vattimo, La Religion. Paris: Seuil, 1996.

("Fichus") "Fichus: Frankfurt Address." Translated by Rachel Bowlby. In Paper; Fichus: Discours de Francfort. Paris: Galilée, 2002. 
("Forgive") "To Forgive: The Unforgivable and the Imprescriptible." Translated by Elizabeth Rottenberg. In Questioning God.

Edited by John D. Caputo et al. Bloomington and Indianapolis: Indiana University Press, 2001. "Pardonner: l'impardonnable et l'impréscriptible," in Derrida.

("Fors") "Fors: The Anglish Words of Nicolas Abraham and Maria Torok." Translated by Barbara Johnson. In Nicolas Abraham and Maria Torok, The Wolf Man's Magic Word. Edited and translated by Nicolas Rand. Minneapolis: Minnesota University Press, 1986; "Fors. Les mots anglés de Nicolas Abraham et Maria Torok." In Nicolas Abraham and Maria Torok, Cryptonymie: Le Verbier de l'homme aux loups. Paris: Aubier-Flammarion, 1976.

("Freud") "Freud and the Scene of Writing." In Writing; "Freud et la scène de l'écriture." In L'Écriture et la différence (see Writing).

(Geneses) Geneses, Genealogies, Genres and Genius: The Secrets of the Archive. Translated by Beverley Bie Brahic. Edinburgh: Edinburgh University Press, 2006; Genèses, généalogies, genres et le génie. Paris: Galilée, 2003.

("Geopsych") "Geopsychoanalysis 'and the rest of the world." Translated by Peggy Kamuf. In Psyche I; "Géopsychanalyse 'and the rest of the world." In Psyché I.

("Geschlecht") "Geschlecht I: Sexual Difference, Ontological Difference." Translated by Ruben Berezdivin and Elizabeth Rottenberg. In Psyche II. "Geschlecht I: Différence sexuelle, différence ontologique.” In Psyché II.

(Glas) Glas. Translated by John P. Leavey, Jr. Lincoln: University of Nebraska Press, 1986; Glas. Paris: Galilée, 1974.

(Grammatology) Of Grammatology. Translated by Gayatri Chakravorty Spivak. Baltimore: Johns Hopkins University Press, 1974, 1976; De la grammatologie. Paris: Minuit, 1967.

(H.C.) H.C. for Life, That Is to Say ... Translated by Laurent Milesi and Stefan Herbrechter. Stanford: Stanford University Press, 2006; H.C. pour la vie, c'est à dire ... Paris: Galilée, 2000. 
("Hand") "Heidegger's Hand (Geschlecht II). Translated by John P. Leavey, Jr. and Elizabeth Rottenberg. In Psyche II; "La Main de Heidegger (Geschlecht II)." In Psyché II.

(Heading) The Other Heading. Translated by Pascale-Anne Brault and Michael B. Naas. Bloomington: Indiana University Press, 1992; L'Autre cap. Paris: Minuit, 1991.

("Illustrate") “To Illustrate, He Said ...” Translated by Peggy Kamuf. In Psyche I; "Illustrer, dit-il ...” In Psyché I.

(“Journalists”) “Above All, No Journalists!” Translated by Samuel Weber. In Religion and Media. Edited by Hent de Vries and Samuel Weber. Stanford: Stanford University Press, 2001.

(“Justices”) “Justices.” Translated by Peggy Kamuf. Critical Inquiry 31, 3 (Spring 2005).

("Khōra") "Khōra." Translated by Ian McLeod. In Name; Khôra. Paris: Galilée, 1993.

("Lacan") "For the Love of Lacan." Translated by Peggy Kamuf. In Resistances of Psychoanalysis. Stanford: Stanford University Press, 1998; Résistances, de la psychanalyse. Paris: Galilée, 1996.

("Law”) “The Law of Genre.” Translated by Avital Ronell. In Acts; "La Loi du genre." In Parages.

(Limited) Limited Inc. Translated by Samuel Weber. Evanston: Northwestern University Press, 1988; Limited Inc. Edited by Elisabeth Weber. Paris: Galilee, 1990.

("Living") "Living On: Borderlines." Translated by James Hulbert. In Harold Bloom et al., Deconstruction and Criticism. New York: Continuum, 1979; "Survivre: Journal de bord.” In Parages.

("Me") "Me-Psychoanalysis." Translated by Richard Klein. In Psyche I; "Moi-la psychanalyse." In Psyché I.

(Memoirs) Memoirs of the Blind: The Self-Portrait and Other Ruins. Translated by Pascale-Anne Brault and Michael Naas. Chicago: University of Chicago Press, 1993; Mémoires d'aveugle: 
L'Autoportrait et autres ruines. Paris: Réunion des Musées Nationaux, 1990.

("Mochlos") "Mochlos, or the Conflict of the Faculties." Translated by Richard Rand and Amy Wygant. In Eyes; "Mochlos, ou le conflit des facultés.” In Du droit à la philosophie. Paris: Galilée, 1990.

(Monolingualism) Monolingualism of the Other; or, the Prosthesis of Origin. Translated by Patrick Mensah. Stanford: Stanford University Press, 1998; Monolinguisme de l'autre, ou la prothèse d'origine. Paris: Galilée, 1996.

(“Mourning”) “By Force of Mourning.” In Work; “À force de deuil." In Chaque fois.

(Name) On the Name. Edited by Thomas Dutoit. Stanford: Stanford University Press, 1995.

(Negotiations) Negotiations: Interventions and Interviews, 19712001. Edited and translated by Elizabeth Rottenberg. Stanford: Stanford University Press, 2002.

("No Apocalypse") "No Apocalypse, Not Now: Full Speed Ahead, Seven Missiles, Seven Missives." Translated by Catherine Porter and Philip Lewis. In Psyche I; "No Apocalypse, not now, à toute vitesse, sept missiles, sept missives." In Psyché I.

(“Oreille") "L'Oreille de Heidegger: Philopolémologie (Geschlecht IV).” In Politiques de l'amitié (see Politics).

(Paper) Paper Machine. Translated by Rachel Bowlby. Stanford: Stanford University Press, 2005; Papier machine. Paris: Galilée, 2002.

(Parages) Parages. Paris: Galilée, 1986.

(“Parjure”) “'Le Parjure,' Perhaps: Storytelling and Lying ('abrupt breaches of syntax')." In Alibi; "Le parjure, peut-être ('brusques sautes de syntaxe').” In Derrida.

("Pas") Pas. In Parages. 
("Passe-Partout”) “Passe-Partout.” In Truth. "Passe-partout.” In La Vérité en peinture (see Truth).

("Passions”) “Passions: 'An Oblique Offering." Translated by David Wood. In Name; Passions. Paris: Galilée, 1993.

("Pharmacy") "Plato's Pharmacy." In Dissemination; "La Pharmacie de Platon." In Dissémination.

(Philosophy) Who's Afraid of Philosophy?: Right to Philosophy 1. Translated by Jan Plug. Stanford: Stanford University Press, 2002; Du droit à la philosophie. Paris: Galilée, 1990 (see also Eyes).

(Points) Points ...: Interviews, 1974-1994. Edited by Elisabeth Weber. Translated by Peggy Kamuf et al. Stanford: Stanford University Press, 1995; Points de suspension: Entretiens. Edited by Elisabeth Weber. Paris: Galilée, 1992.

(Politics) Politics of Friendship. Translated by George Collins. London: Verso, 1997; Politiques de l'amitié. Paris: Galilée, 1994.

(Positions) Positions. Translated by Alan Bass. Chicago: University of Chicago Press, 1982; Positions. Paris: Minuit, 1972.

(Post Card) The Post Card: From Socrates to Freud and Beyond. Translated by Alan Bass. Chicago: University of Chicago Press, 1987; La Carte postale, de Socrate à Freud et au-delà. Paris: AubierFlammarion, 1980.

("Psyche") "Psyche: Invention of the Other." Translated by Catherine Porter. In Psyche I; "Psyché: Invention de l'autre." In Psyché I.

(Psyche) Psyche: Inventions of the Other, volumes I and II. Edited by Peggy Kamuf and Elizabeth Rottenberg. Stanford: Stanford University Press, 2007 and 2008; Psyché: Inventions de l'autre, tomes I et II. Paris: Galilée, 1998 and 2003.

(“Qual Quelle”) “Qual Quelle: Valéry's Sources.” In Margins of Philosophy. Translated by Alan Bass. Chicago: University of Chicago Press, 1985; "Qual quelle, les sources de Valéry.” In Marges—de la philosophie. Paris: Minuit, 1972. 
(“Racism”) “Racism's Last Word.” Translated by Peggy Kamuf. In Psyche I; "Le Dernier mot du racisme." In Psyché I.

("Rams") "Rams: Uninterrupted Dialogue-Between Two Infinities, the Poem." Translated by Thomas Dutoit and Philippe Romanski. In Sovereignties; Béliers, Le Dialogue ininterrompu: entre deux infinis, le poème. Paris: Galilée, 2003.

("Rhetoric") “The Rhetoric of Drugs.” Translated by Michael Israel. In Points; "La Rhétorique des drogues." In Points.

("Restitutions") "Restitutions: Of the Truth in Painting." In Truth; "Restitutions, de la vérité en peinture. In La Vérité en peinture (see Truth).

(Rogues) Rogues: Two Essays on Reason. Translated by PascaleAnne Brault and Michael Naas. Stanford: Stanford University Press, 2005; Voyous: Deux essais sur la raison. Paris: Galilée, 2003.

(“Salut”) “'Dead Man Running': Salut, Salut.” In Negotiations; “'Il courait mort': Salut, salut." Les Temps Modernes 587, Mars-Mai, 1996.

("Sauf") "Sauf le nom (Post-Scriptum)." Translated by John P. Leavey, Jr. In Name; Sauf le nom. Paris: Galilée, 1993.

(Signéponge) Signéponge/Signsponge. Translated by Richard Rand. New York: Columbia University Press, 1984 [bilingual edition]; Signéponge. Paris: Éditions du Seuil, 1988.

("Silk Worm”) “A Silk Worm of One's Own.” Translated by Geoffrey Bennington. In Hélène Cixous and Derrida, Veils. Stanford: Stanford University Press, 2001; “Un ver à soie.” In Hélène Cixous and Derrida, Voiles. Paris: Galilée, 1998.

(Sovereignties) Sovereignties in Question: The Poetics of Paul Celan. Edited by Thomas Dutoit and Outi Pasanen. New York: Fordham University Press, 2005.

(Specters) Specters of Marx: The State of the Debt, the Work of Mourning, and the New International. Translated by Peggy Kamuf. New York and London: Routledge, 1994; Spectres de Marx: L'État 
de la dette, le travail du deuil et la Nouvelle Internationale. Paris: Galilée, 1993.

(“Speculate”) “To Speculate—on 'Freud.”" In Post Card; "Spéculersur 'Freud." In La Carte postale (see Post Card).

(Speech) Speech and Phenomena and Other Essays on Husserl's Theory of Signs. Translated by David B. Allison. Evanston: Northwestern University Press, 1973; La Voix et le phénomène. Paris: Presses Universitaires de France, 1967.

("States") "Psychoanalysis Searches the States of Its Soul." In Alibi; États d'âme de la psychanalyse. Paris: Galilée, 2000.

("Structure") "Structure, Sign and Play in the Discourse of the Human Sciences." In Writing; "La Structure, le signe et le jeu dans le discours des sciences humaines"; In L'Écriture et la différence (see Writing).

(“Telepathy") “Telepathy." Translated by Nicholas Royle. In Psyche I; "Télépathie." In Psyché I.

(“This Work") "At This Very Moment in This Work Here I Am." Translated by Ruben Berezdivin and Peggy Kamuf. In Psyche I. "En ce moment même dans cette oeuvre me voici.” In Psyché I.

(Time) Given Time: 1. Counterfeit Money. Translated by Peggy Kamuf. Chicago: University of Chicago Press, 1992; Donner le temps: 1. La Fausse monnaie. Paris: Galilée, 1991.

(Tomorrow) Derrida and Elisabeth Roudinesco. For What Tomorrow: A Dialogue. Translated by Jeff Fort. Stanford: Stanford University Press, 2004; Derrida and Elisabeth Roudinesco, De quoi demain: Dialogue. Paris: Fayard and Galilée, 2001.

("Tone") "On a Newly Arisen Apocalyptic Tone in Philosophy." Translated by John P. Leavey, Jr. In Raising the Tone of Philosophy: Late Essays of Immanuel Kant, Transformative Critique of Jacques Derrida. Edited by Peter Fenves. Baltimore: The Johns Hopkins University Press, 1993; D’un ton apocalyptique adopté naguére en philosophie. Paris: Galilée, 1983-2005. 
(Touching) On Touching-Jean-Luc Nancy. Translated by Christine Irizarry. Stanford: Stanford University Press, 2005; Le Toucher, Jean-Luc Nancy. Paris: Galilée, 2001.

(Tourner) Derrida and Safaa Fathy. Tourner les mots: Au bord d'un film. Paris: Galilée, 2000.

(“Tout") “Du tout." In Post Card; "Du tout." In La Carte postale (see Post Card).

(Truth) The Truth in Painting. Translated by Geoff Bennington and Ian McLeod. Chicago: University of Chicago Press, 1987; La Vérité en peinture. Paris: Flammarion, 1978.

("Ulysses") "Ulysses Gramophone: Hear Say Yes in Joyce." Translated by Tina Kendall and Shari Benstock. In Acts; "Ulysse gramophone: ouï-dire de Joyce." In Ulysse Gramophone: Deux mots pour Joyce. Paris: Galilée, 1987.

("Unconditionality") "Unconditionality or Sovereignty: The University at the Frontiers of Europe." Translated by Peggy Kamuf. Oxford Literary Review 31, 2 (2009); "Inconditionnalité ou souveraineté: L'Université aux frontières de l'Europe.” Athènes: Éditions Patakis, 2002.

(“University”) “The University Without Condition." In Alibi; L’Université sans condition. Paris: Galilée, 2001.

("Witnessing") “The Poetics and Politics of Witnessing." Translated by Outi Pasanen. In Sovereignties; "Poétique et politique du témoignage." In Derrida.

(Work) The Work of Mourning. Edited and translated by PascaleAnne Brault and Michael Naas. Chicago: University of Chicago Press, 2001; see Chaque fois.

(Writing) Writing and Difference. Translated by Alan Bass. Chicago: University of Chicago Press, 1978; L'Écriture et la différence. Paris: Éditions du Seuil, 1967. 